Jurnal Sporta Saintika

P-ISSN 2502-5651

E-ISSN 2579-5910

\title{
TINJAUAN KEBUGARAN JASMANI SISWA SEKOLAH DASAR
}

\author{
Dessi Novita Sari \\ Universitas Negeri Padang, Pendidikan Jasmani Kesehatan dan Rekreasi, Padang, \\ Indonesia \\ dessinovita10@fik.unp.ac.id
}

\begin{abstract}
The problem in this research is that the level of physical fitness of the students at SD Negeri 11 Kampung Jawa, Kota Solok is not yet known. The formulation of the problem in this study is how the level of physical fitness of students of SD Negeri 11 Kampung Jawa, Kota Solok. The purpose of this study was to determine the physical fitness of students of SD Negeri 11 Kampung Jawa, Kota Solok. The purpose of this study was to determine the physical fitness of elementary school students. The research method uses quantitative methods with survey techniques. The population is 36 and the research sample is 18 people. The sampling technique used was proportional sampling. Data collection used a physical fitness test for Indonesian children aged 10-12 years. Based on the test results and field data findings, it can be concluded that the fifth grade students of SD Negeri 11 Kampung Jawa, Kota Solok. The data analysis technique is descriptive. The purpose of this study was to determine the level of physical fitness of female students who were in the average group of 12 people $(66.67 \%)$, while those above the average group were 4 people $(22.22 \%)$ and those who were below average. -Average of 2 people (11.11\%).
\end{abstract}

Key word: survey, physical fitness, students

\begin{abstract}
Abstrak
Masalah dalam penelitian ini adalah belum diketahui tingkat kebugaran jasmani siswa SD negeri 11 Kampung Jawa Kota Solok. Rumusan masalah dalam penelitian ini adalah bagaimana tingkat kebugaran jasmani siswa SD negeri 11 Kampung Jawa Kota Solok. Tujuan penelitian ini adalah untuk mengetahui kebugaran jasmani siswa SD negeri 11 Kampung Jawa Kota Solok. Tujuan penelitian ini adalah untuk mengetahui kebugaran jasmani siswa SD. Metode penelitian menggunakan metode kuantitatif dengan teknik survey. Populasi berjumlah 36 dan sampel penelitian berjumlah 18 orang. Teknik pengambilan sampel yang digunakan yaitu proportional sampling. Pengumpulan data menggunakan tes kebugaran jasmani anak Indonesia usia 10-12th. Berdasarkan hasil tes dan temuan data dilapangan, dapat disimpulkan bahwa siswa kelas V SD Negeri negeri 11 Kampung Jawa Kota Solok. Teknik analisis data yaitu deskriptif. Tujuan penelitian ini adalah untuk mengetahui tingkat kebugaran jasmani siswa putri yang berada pada kelompok rata-rata sebanyak 12 orang $(66,67 \%)$, sedangkan di atas kelompok rata-rata sebanyak 4 orang ( $22,22 \%)$ dan yang berada di bawah rata-rata sebanyak 2 orang $(11,11 \%)$.
\end{abstract}

Kata Kunci : tingkat kebugaran jasmani

\section{PENDAHULUAN}

Pendidikan adalah salah satu pilar utama dalam pembangunan nasional. Melalui pendidikan kita bisa mempersiapkan sumber daya manusia yang bermutu baik. Untuk mencapai tujuan pendidikan di atas, salah satu program pemerintah dalam mewujudkannya

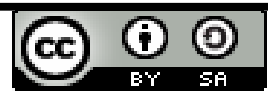

Volume 5, Nomor 2, September 2020 sportasaintika.ppj.unp.ac.id 
Jurnal Sporta Saintika

P-ISSN 2502-5651

E-ISSN 2579-5910

adalah dengan pembinaan pendidikan di Sekolah Dasar. Pendidikan Sekolah Dasar adalah suatu lembaga pendidikan yang memberikan bekal kepada siswa untuk melanjutkan pendidikannya kejenjang yang lebih tinggi dan sering juga disebut masa usia sekolah dasar adalah masa intelektual atau masa keserasian bersekolah.

Bila ditinjau dari mata pelajaran yang ada di Sekolah Dasar, pelajaran pendidikan jasmani merupakan salah satu mata pelajaran dan bahan kajian yang termuat dalam kurikulum sekolah dasar yang merupakan proses pembelajaran yang bertujuan untuk meningkatkan kebugaran jasmani, pengembangan keterampilan motorik, pengetahuan dan perilaku hidup aktif dan bersikap sportif melalui kegiatan jasmani.

Berdasarkan pernyataan di atas dapat diartikan bahwa kebugaran jasmani memiliki peranan yang penting dalam kegiatan sehari-hari siswa, karena kebugaran jasmani yang baik sangat diperlukan oleh siswa, baik dalam mengikuti proses pembelajaran di sekolah maupun dalam pencapaian prestasi di luar sekolah. Namun dari hasil pengamatan ditemukan bahwa tidak $1 \%$ pun siswa setamat Sekolah Dasar memiliki kebugaran jasmani dengan kategori baik sekali, hanya 14,8\% siswa yang memiliki tingkat kebugaran jasmani dengan kategori baik.

Selanjutnya hasil hasil penelitian yang dilakukan oleh Jurusan Pendidikan Olahraga pada tahun 2017 terhadap 558 orang peserta didik di Kota Padang ditemukan, tingkat kebugaran jasmani peserta didik tersebut tidak satupun yang berada dalam kategori baik dan baik sekali.

(Komaini, 2017) Secara umum kebugaran jasmani dapat diartikan sebagai kemampuan seseorang melakukan kerja sehari-hari secara efisien tanpa menimbulkan kelelahan yang berlebihan sehingga masih dapat menikmati waktu luang. (Hardiansyah, 2017) kesegaran jasmani merupakan keadaan tubuh untuk dapat melakukan kegiatan sehari-hari tanpa mengalami kelelahan yang berarti. (Adi, 2010) Kebugaran adalah suatu keadaan dimana seseorang melakukan tugas atau pekerjaan fisik tidak merasakan kelelahan disaat melakukan pekerjaan atu tugas tersebut. (Yusuf, 2018) Kebugaran jasmani pengertiannya yaitu kemampuan tubuh seseorang untuk melakukan pekerjaan sehari-hari tanpa menimbulkan kelelahan yang berarti.

Dari pendapat di atas dapat disarikan bahwa kebugaran jasmani itu merupakan kemampuan individu untuk melakukan tugasnya sehari- hari tanpa mengalami kelelahan yang berarti serta masih mempunyai cadangan energi untuk menikmati waktu senggangnya serta keperluan yang sifatnya mendadak.

Kebugaran jasmani terdiri dari beberapa komponen seperti yang dikemukakan sportasaintika.ppj.unp.ac.id 
Jurnal Sporta Saintika

P-ISSN 2502-5651

E-ISSN 2579-5910

(Suharjana, 2013) "komponen kebugaran jasmani terdiri dari kebugaran jasmani yang berkaitan dengan kesehatan, yang mengandung unsur empat pokok yaitu: kekuatan otot, daya tahan otot, daya tahan aerobik, dan fleksibilitas, serta kebugaran jasmani yang berkaitan dengan performance, mengandung unsur: koordinasi, kelincahan, kecepatan gerak, dan keseimbangan. (Gusril, 2004) Komponen kesegaran jasmani di antaranya adalah: 1) Kekuatan otot adalah kualitas yang memungkinkan terjadinya kontraksi sekelompok otot secara maksimal. Dayatahan otot adalah kualitas yang membuat seseorang mampu mengarahkan kekuatan/tenaga sekelompok otot secara berulang kali (dinamis), di bawah maksimal atau mempertahankan kontraksi dalam waktu tertentu; 2) Ketahanan cardiovaskuler respiratory dapat ditafsirkan sebagai kualitas fisik (sistem jantung, paruperedaran darah secara terus menerus suatu kerja fisik yang cukup berat tanpa merasa lelah sebelum waktunya; 3) Daya otot adalah kemampuan otot mengeluarkan daya maksimal dalam waktu tercepat. Daya otot yang besar dimiliki oleh orang-orang yang mempunyai: (a) kekuatan besar, (b) kecepatan tinggi, (c) kecepatan menginteraksi kekuatan dan kecepatan; 4) Fleksibilitas adalah kualitas yang memungkinkan terjadinya peregangan otot secara maksimal tanpa menimbulkan cedera pada persendian di tempat otot tersebut berada. Kecepatan adalah kemampuan untuk memindahkan sebagian atau seluruh tubuh pada jarak tertentu dalam waktu sesingkat-singkatnya. Ditambahkan kecepatan merupakan sejumlah gerakan per unit waktu; 5) Kelincahan diartikan sebagai kemampuan.

(Agus, 2012) faktor-faktor yang mempengaruhi kebugaran jasmani seseorang adalah aktivitas, keturunan, usia, jenis kelamin. Banyak faktor lain yang mempengaruhi tingkat kebugaran jasmani siswa diantaranya yaitu usia, jenis kelamin, kebiasaan siswa dalam aktifitas fisik seperti latihan-latihan olahraga dan aktifitas bermain, sarana dan prasarana yang baik dapat mempengaruhi siswa aktif dalam pembelajaran penjasorkes yang dalam proses pembelajarannya erat kaitannya dengan kerja fisik, lingkungan yang bersih dan nyaman, pengetahuan dan pendidikan, ekonomi orang tua, istirahat yang cukup, serta kondisi fisik, semua ini dapat mempengaruhi tingkat kebugaran jasmani siswa.

\section{METODELOGI PENELITIAN}

Dalam penelitian ini, metode penelitian yang digunakan adalah metode deskriptif, yaitu metode yang membicarakan beberapa kemungkinan untuk memecahkan masalah dengan jalan mengumpulkan data menyusun, atau mengklasifikasikan. Populasi berjumlah 36 orang sedangkan sampel berjumlah 18 orang. Teknik penarikan sampel yang digunakan yaitu proportional sampling. Menurut (Margono, 2004) penentuan sampel perlu memperhatikan sifat dan penyebaran populasi. Sampel yang digunakan yaitu siswa putri. 
Jurnal Sporta Saintika

P-ISSN 2502-5651

E-ISSN 2579-5910

Pengumpulan data menggunakan tes Kebugaran Jasmani Anak Indonesia (TKJI). Analisis Data menggunakan deskripsi persentase. Instrumen yang digunakan adalah Tes Kesegaran Jasmani Jasmani Indonesia. Untuk menentukan tingkat kebugaran jasmani siswa Sekolah Dasar. Kemendiknas (2010:4) mengemukakan bahwa Tes Kebugaran Jasmani Indonesia (TKJI) untuk siswa Sekolah Dasar (Usia 10 - 12 Tahun) yaitu : 1) Tes kecepatan (Lari 40 meter $\mathrm{Pa} / \mathrm{Pi}$ ); 2) Tes kekuatan otot lengan (Gantung siku tekuk $\mathrm{Pa} / \mathrm{Pi}$ ); 3) Tes kekuatan otot perut (Baring duduk selama 30 detik $\mathrm{Pa} / \mathrm{Pi}$ ); 4) Tes daya ledak otot tungkai (Loncat Tegak); 5) Tes daya tahan (Lari 600 meter untuk putra dan putri).

\section{HASIL PENELITIAN}

\section{Data Tingkat Kebugaran Jasmani Siswa Putri}

Dari 18 orang siswa putri, didapatkan data dengan skor tertinggi yaitu 16 dan skor terendah 7. Berdasarkan data tersebut rata- rata hitung (mean) 12,5 dan simpangan baku $(S D)$ 2,3. Untuk lebih jelasnya distribusi frekuensi dilihat pada tabel 1

Tabel 1. Data Tingkat Kebugaran Jasmani Putri

\begin{tabular}{|c|c|c|c|}
\hline No & Jumlah Nilai & $\mathbf{F a}$ & Fr \\
\hline 1 & $5-9$ & 2 & 11,11 \\
\hline 2 & $10-13$ & 12 & 66,67 \\
\hline 3 & $14-17$ & 4 & 22,22 \\
\hline 4 & $18-21$ & 0 & 0,00 \\
\hline 5 & $22-25$ & 0 & 0,00 \\
\hline \multicolumn{2}{|r|}{ Jumlah } & 18 & 100 \\
\hline
\end{tabular}

Dari tabel 1 di atas, terlihat bahwa tingkat kebugaran jasmani siswa putri yang berada pada kelompok rata-rata sebanyak 12 orang $(66,67 \%)$, sedangkan di atas kelompok rata-rata sebanyak 4 orang $(22,22 \%)$ dan yang berada di bawah rata-rata sebanyak 2 orang $(11,11 \%)$.

\section{PEMBAHASAN}

Dari hasil yang ditemukan dalam penelitian bahwa siswa SD terlihat bahwa tingkat kebugaran jasmani siswa putri yang berada pada kelompok rata-rata sebanyak 12 orang $(66,67 \%)$, sedangkan di atas kelompok rata-rata sebanyak 4 orang ( $22,22 \%)$ dan yang berada di bawah rata-rata sebanyak 2 orang $(11,11 \%)$.

Tujuan penelitian ini yaitu untuk melihat tingkat kebugaran jasmani. Melihat hasil temuan dari penelitian ini, tentunya perlu mendapatkan perhatian yang serius dalam 
Jurnal Sporta Saintika

P-ISSN 2502-5651

E-ISSN 2579-5910

rangka meningkatkan kebugaran jasmani. (Rizki Habibullah, 2020) mengungkapkan Begitu pentingnya kebugaran jasmani yang harus dimiliki anak, mewajibkan seluruh sekolah harus selalu mengukur tingkat kebugaran jasmani anak. Sehingga dengan hasil tersebut kebugaran anak dapat terus terpantau dengan baik, efektif dan efesien. Dalam menjaga kesehatan dan usaha meningkatkan kesegaran jasmani maka merupakan faktor penting yang harus diperhatikan (Sepriadi, Sefri Hardiansyah, 2017).

\section{KESIMPULAN}

Dari penelitian tingkat kebugaran jasmani siswa putri pada kategori sangat kurang 2 orang, pada kategori kurang 12 orang, kategori sedang 4 orang, tidak ada yang kategori baik dan kategori baik sekali.

Dapat dikatakan bahwa tingkat kebugaran jasmani siswa putri yang berada pada kelompok rata-rata sebanyak 12 orang $(66,67 \%)$, sedangkan di atas kelompok rata-rata sebanyak 4 orang $(22,22 \%)$ dan yang berada di bawah rata-rata sebanyak 2 orang $(11,11 \%)$.

\section{DAFTAR PUSTAKA}

Adi, B. S. (2010). Meningkatkan Kebugaran Jasmani Anak SD Melalui Latihan Kebugaran Aerobik. Skripsi.

Agus, A. (2012). Olahraga Kebugaran Jasmani Sebagai Suatu Pengantar. Sukabina Press.

Gusril. (2004). Belajar Keterampilan Motorik Pengantar ri dan Metoda. DEPDIKBUD.

Hardiansyah, S. (2017). PENGARUH METODE INTERVAL TRAINING TERHADAP PENINGKATAN KESEGARAN JASMANI MAHASISWA JURUSAN PENDIDIKAN $\begin{array}{lll}\text { OLAHRAGA. Jurnal PENJAKORA, } & \text { 83-92. }\end{array}$ https://ejournal.undiksha.ac.id/index.php/PENJAKORA/article/viewFile/13369/8401

Komaini, A. (2017). PROFIL TINGKAT KESEGARAN JASMANI KARYAWAN FAKULTAS ILMU KEOLAHRAGAAN UNIVERSITAS NEGERI PADANG. Jurnal Sporta Saintika, 2, 1-15. http://repository.unp.ac.id/6530/1/Jurnal Sporta Saintika Maret 2017 OK.pdf Margono. (2004). Metodologi Penelitian Pendidikan. Rineka Cipta.

Rizki Habibullah. (2020). Tinjauan Kebugaran Jasmani SD Negeri 18 Palembang. Seminar Ansional Olahraga, 2(1), 215-222. https://semnas.univpgripalembang.ac.id/index.php/semolga/article/download/105/109.

Sepriadi, Sefri Hardiansyah, H. S. (2017). Perbedaan Tingkat Kesegaran Jasmani

Berdasarkan Status Gizi. Jurnal Media IImu Keolahragaan Indonesia, 7, 24-34.

https://journal.unnes.ac.id/nju/index.php/miki/article/view/10934/0

Suharjana. (2013). Kebugaran Jasmani. Jogja Global Media. 
Jurnal Sporta Saintika

P-ISSN 2502-5651

E-ISSN 2579-5910

Yusuf, H. (2018). EVALUASI KEBUGARAN JASMANI MELALUI HARVARD STEP TESTPADA MAHASISWAPJKR TAHUN2016/2017 IKIP BUDI UTOMO. JP.JOK (Jurnal Pendidikan Jasmani, Olahraga Dan Kesehatan). https://doi.org/10.33503/jpjok.v1i2.162 